\title{
THE IDENTIFICATION OF LIVING MALIGNANT IN EXUDATES
}

\author{
BY \\ R. J. V. PULVERTAFT AND L. WEISS \\ From the John Burford Carlill Pathological Laboratories, Westminster School of Medicine, London
}

(RECEIVED FOR PUBLICATION JUNE 3, 1957)

The examination of exudates from serous cavities for malignant cells presents some difficulties in technique, in addition to the problem of identifying neoplastic cells. This communication deals with experiences in examining about 500 exudates for such cells and their culture.

All of the exudates were examined in the first instance by phase-contrast microscopy and about half were further examined by tissue-culture techniques and in fixed films.

\section{Method}

Collection of Specimens.-As much as possible of the total aspirate was collected and thoroughly mixed with a suitable anticoagulant. Citrate and heparin, $3.8^{\circ}$, have both been satisfactory. Sequestrene (disodium salt of ethylenediamine tetra-acetic acid) used in solution as recommended by Hadley and Larson (1953) has been found toxic to living cells in exudates. This toxic effect of sequestrene is curious, as its use has been advocated by Zwilling (1954) for cell dispersion in tissue culture techniques.

The exudates were examined as soon as possible after collection, as cells kept overnight show decreased viability. This is lessened by keeping the fluids at $4^{\circ} \mathrm{C}$., but the resultant cultures are usually poor.

The Clotted Specimen.-The clotted specimen is occasionally met with, and malignant cells are often taker. up by the clot. Such clots have been digested by treatment in $0.25 \%$ trypsin (Difco $1: 250$ ) in phosphate-buffered saline (Dulbecco and Vogt, 1954) for 30 to 40 minutes at $37^{\circ} \mathrm{C}$. After such treatment. neoplastic cells are usually liberated. These cells are identifiable by phase-contrast microscopy and are suitable for culture.

The Haemorrhagic Specimen.-Very haemorrhagic exudates have in the past been looked upon as poor diagnostic material, because of the difficulty in finding comparatively few malignant cells among many erythrocytes. Ordinary centrifugation may often prove useless for separation. The methods of flotation in bovine albumin described by Fawcett and Vallee (1952) and Fawcett, Vallee, and Soule (1950) is both laborious and expensive. The method noted by
Humble, Jayne, and Pulvertaft (1956), in which the total deposit from $50 \mathrm{ml}$. centrifuge cups is recentrifuged in haematocrit tubes for 30 minutes at 3,000 r.p.m., has been used. Malignant cells tend to collect in the buffy coat from whence they may be pipetted. Spriggs (1957) remarks that this technique is seldom applicable; however, following extensive use of this method, it seems to be the best available for dealing with the haemorrhagic exudate.

Phase-contrast Examination.-Care must be taken to lower the cover-slip very gently on to a drop of cell suspension on a slide. If a cover-slip is put im place forcibly, three-dimensional aggregates of neor plastic cells, which are the keystone of diagnosis b this method, are broken up. This simple method of examining living cells is to be preferred to fixe films in which the characteristic relationship between cells is often disturbed. Also, more cytological detail is visible than in such films.

Culture of Exudates.-Exudates have been cultured on agar-capped roller-slides (Pulvertaft, Haynes, and Groves, 1956) and in bottles.

A drop of dilute cell suspension in culture fluid is put on the central agar pillar. The slide is then covered with a petri dish lid and left at room temperature for 15 minutes. After this time the cells will have sedimented on to the agar, and the excess fluid may be removed with a finely drawn Pasteur pipette. A cover-slip is then gently lowered into position and fixed to the slide with beeswax. The side-vents are plugged with molten beeswax and the slide is observed on the stage of a phase-contrast microscope (with a long working distance condenser) in a "hot-box" at $37^{\circ} \mathrm{C}$.

After some two hours the cells flatten out in the capillary space between the cover-slip and the agar pillar, and a wealth of cytological detail may be seen. After 12 hours the beeswax plugs in the sidevents are removed and culture fluid is introduced. The slides are then placed on a roller (1 r.p.m.) in between observations.

Recently a modification of the roller slide in which the central pillar is cupped and takes a thicker agar plug than in that originally described has been used (Fig. 1). 

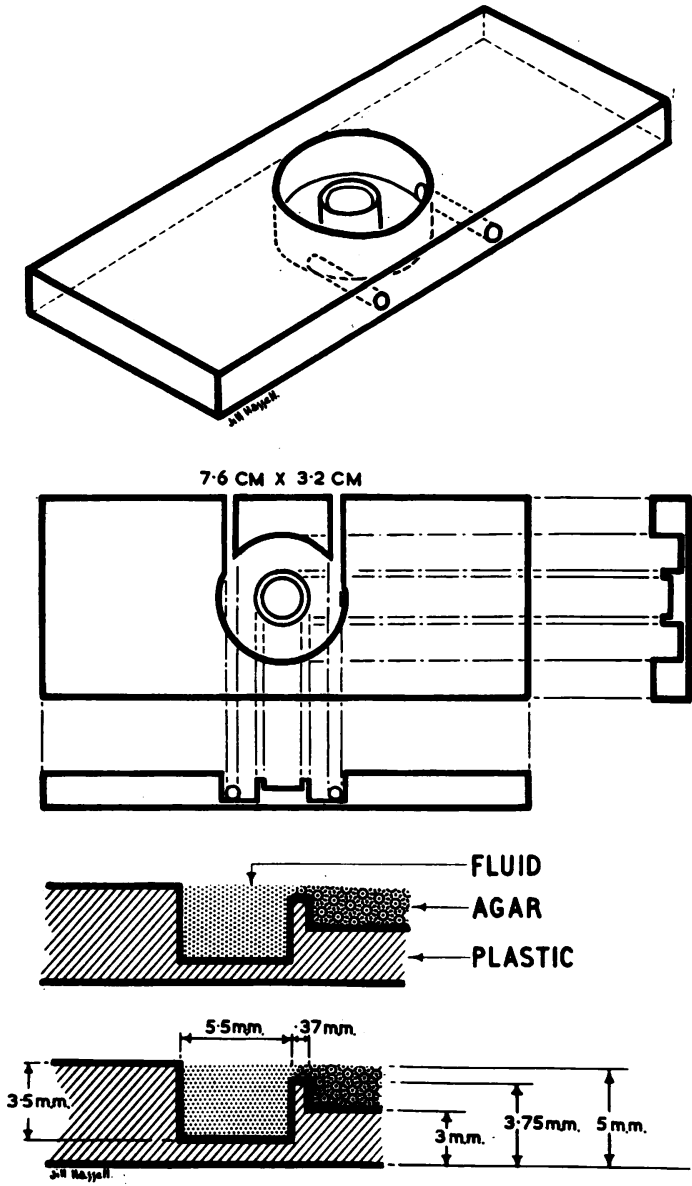

Fig. 1.-Improved roller slide.

Bottle culture of exudates is a far simpler procedure. Cells are suspended in 2 or $10 \mathrm{ml}$. of culture fluid and placed in Kingsley Sanders (P.M.2) bottles or pyrex baby feeding bottles respectively. The bottles are incubated lying flat.

Culture Fluids. - The fluid currently in use is based on a formula given by Syverton (1957) and consists of :

$\begin{array}{lrrrr}\text { Hanks fluid } & \ldots & \ldots & \ldots & 80 \text { parts } \\ 1 \% \text { Bacto yeast } \ldots & \ldots & \ldots & 10 \text { parts } \\ \text { Inactivated human } & \text { serum } & \ldots & 10 \text { parts } \\ 10 \% \text { glucose } & \ldots & \ldots & \ldots & 2.5 \text { parts }\end{array}$

+ Penicillin, 100 units $/ \mathrm{ml}$.

Streptomycin, $100 \mu \mathrm{g} . / \mathrm{ml}$.

Nystatin, 100 units $/ \mathrm{ml}$.

Fixed films stained by Papanicoloau's method or by a Leishman-Giemsa technique have been used for purposes of comparison with the other method employed.

\section{Criteria of Malignancy in Living Cells}

The most constant criterion of malignancy in the authors' experience has been the presence of three-dimensional aggregates of cells. These vary in size from clumps of several cells to the "cancer-balls" containing hundreds. These should not be confused with clumps of macrophages or mesothelial cells, which tend to be

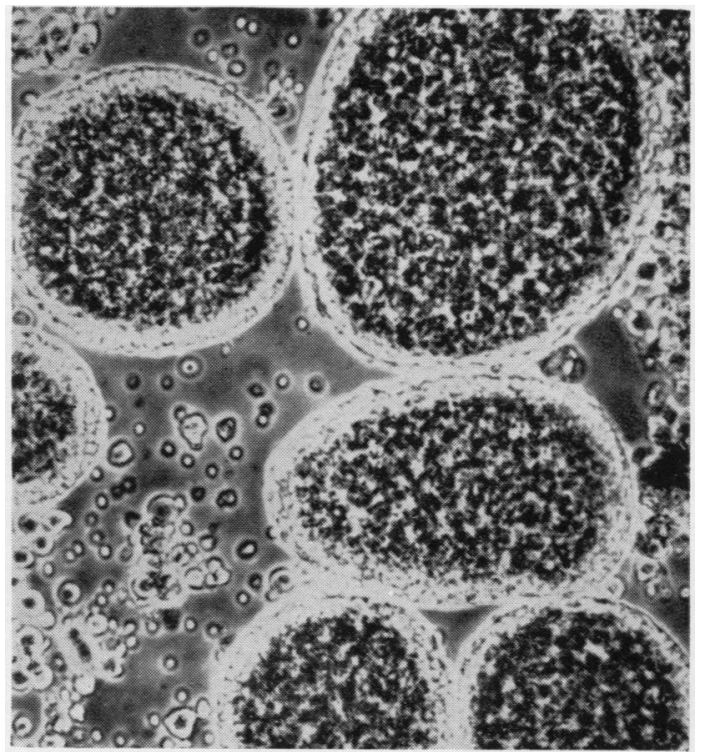

Fig. 2.-Pleural effusion showing " cancer-balls" in bronchogenic carcinoma. $\times 165$.

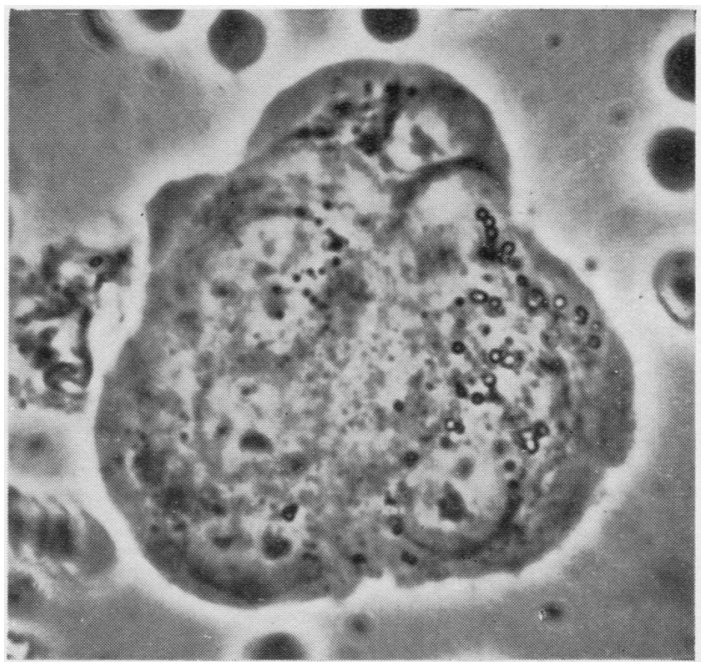

FIG. 3.-Pleural effusion showing three-dimensional aggregate of neoplastic cells in mammary carcinoma. Phase, $\times 960$. 
smaller, have a correct nuclear/cytoplasmic ratio, and are not pleomorphic to any marked extent. By phase-contrast, the cytoplasm of malignant cells often appears grey. This is probably due in part to increased concentration of cytoplasmic

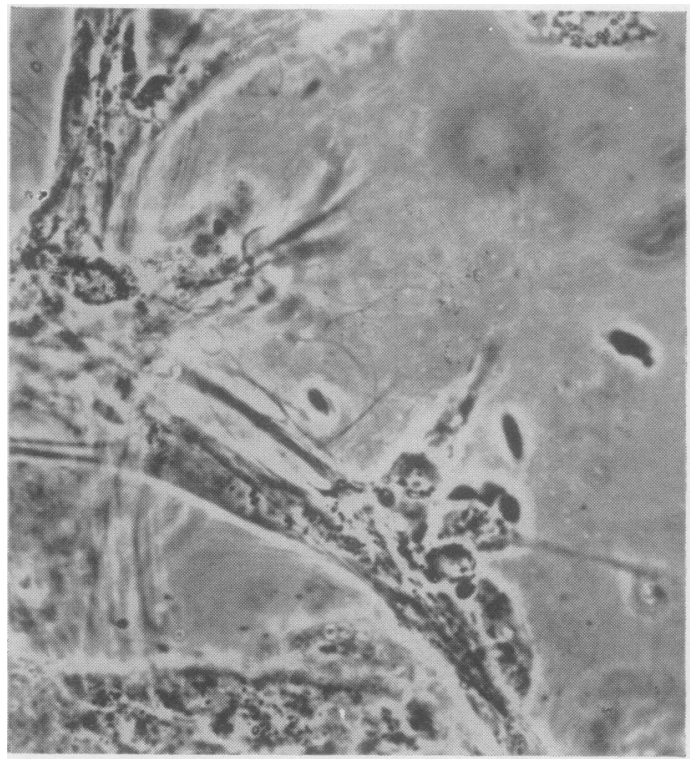

FIG. 4._"Whiskery" appearance in pseudomyxoma peritonei (ovarii). $\times 300$.

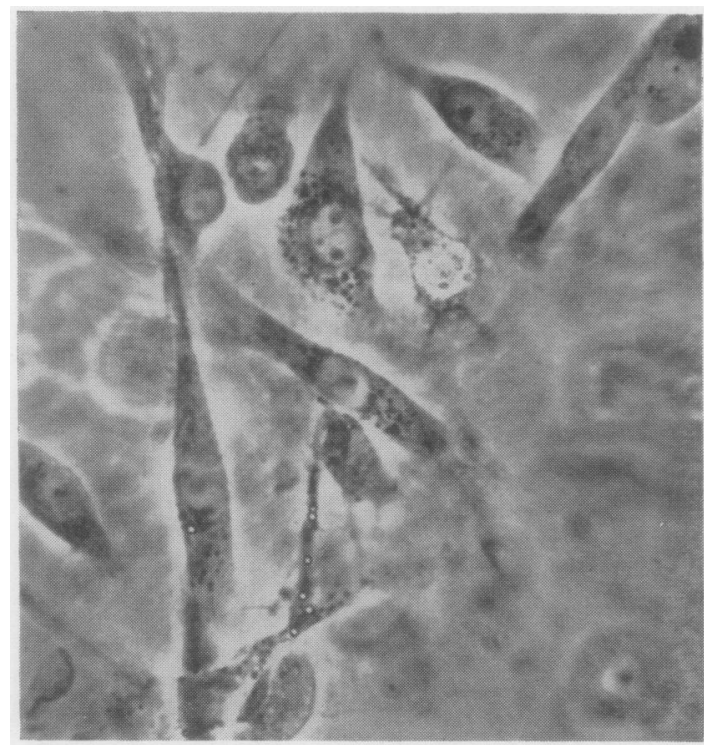

Fio. 6.-Ascitic fluid showing mesothelial cells in carcinomatosis adopting fibroblast-like form after 24 hours' culture on a roller slide. Phase, $\times \mathbf{4 5 0}$. constituents compared with most normal cells. Single cells may often be identified by abnormal size and bizarre appearance. Other criteria of malignancy include anisocytosis, moulding, an inverse nuclear-cytoplasmic ratio, and prominent

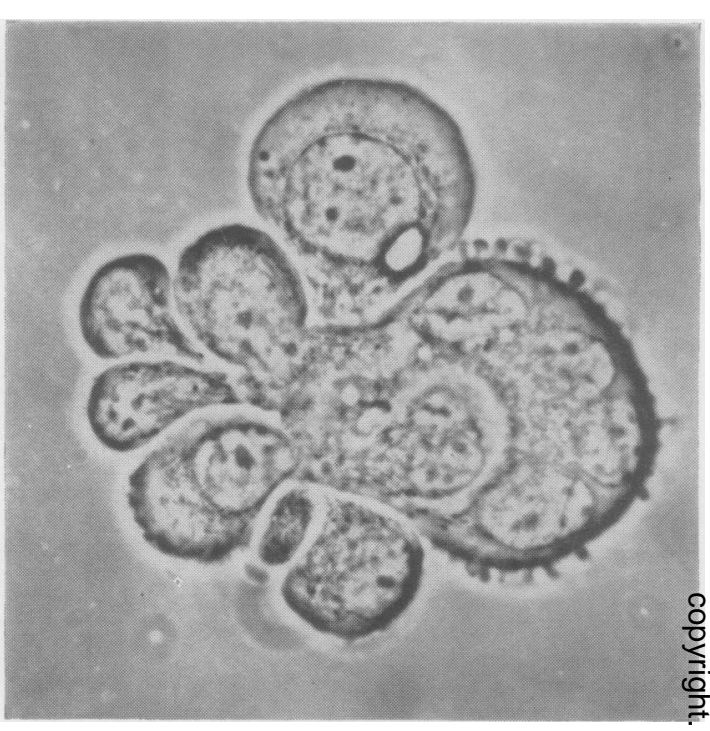

FIG. 5.-Pleural effusion showing flattened aggregate of neoplastic cells in mammary carcinoma. Note moulding and anisocytosis. Phase, $\times 560$.

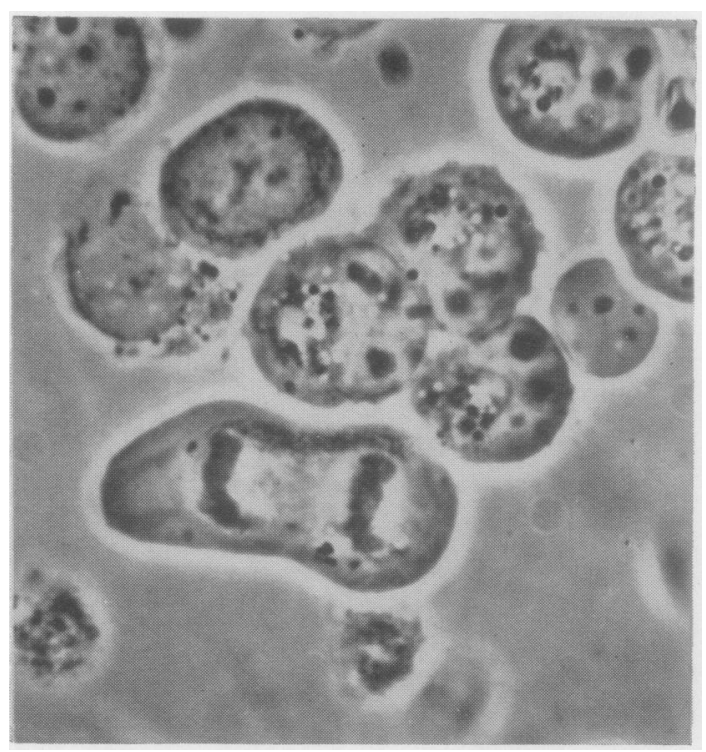

Fig. 7.-Pleural effusion showing cell in mitosis after several hours on a roller slide in bronchogenic carcinoma. Phase, $\times 1,100$. 


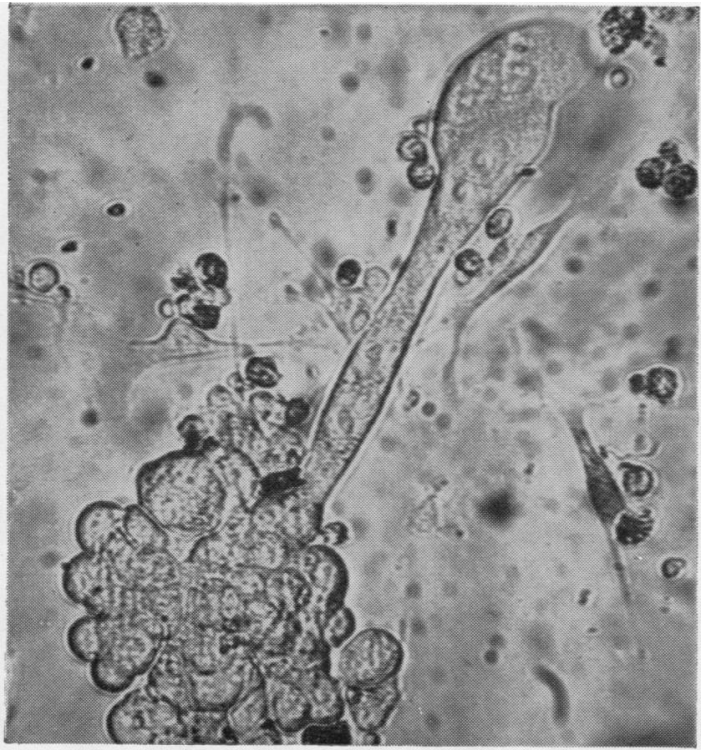

FIG. 8.-Ascitic fluid showing flattened plaque of neoplastic cells after 72 hours' bottle culture. Gastric carcinoma. Note attachment of spreading cells to main clump. $\times 105$.

nucleoli. Potocytosis is seen in both malignant cells and macrophages, but is more marked in the former.

Mention must be made of the failure to make a diagnosis by phase-contrast of exudates from patients suffering from the " reticuloses."

By phase-contrast microscopy, deposits from pseudomyxoma peritonei show a characteristic "whiskery" appearance.

\section{Behaviour of Cells in Culture}

After some 12 hours in a bottle, viable neoplastic cells and macrophages stick to the glass. At this time the macrophages tend to spread in fibroblast-like form whereas the malignant cells usually are still rounded and in clumps. By gently washing, all other cells may be removed from the bottle. This is advisable, as degenerating erythrocytes exert a deleterious effect on the cells sticking to the glass. Twelve hours' incubation may thus be used as a concentration method for malignant cells and macrophages.

After several days' culture, neoplastic cells are seen to form flattened plaques from which occasional cells may migrate a short distance without losing their connexion with the main plaque.

After some 200 attempts the authors have not to date succeeded in establishing permanent strains of malignant cells from exudates. This may well be a reflection of the diminished viability of the cells which are found free in exudates.

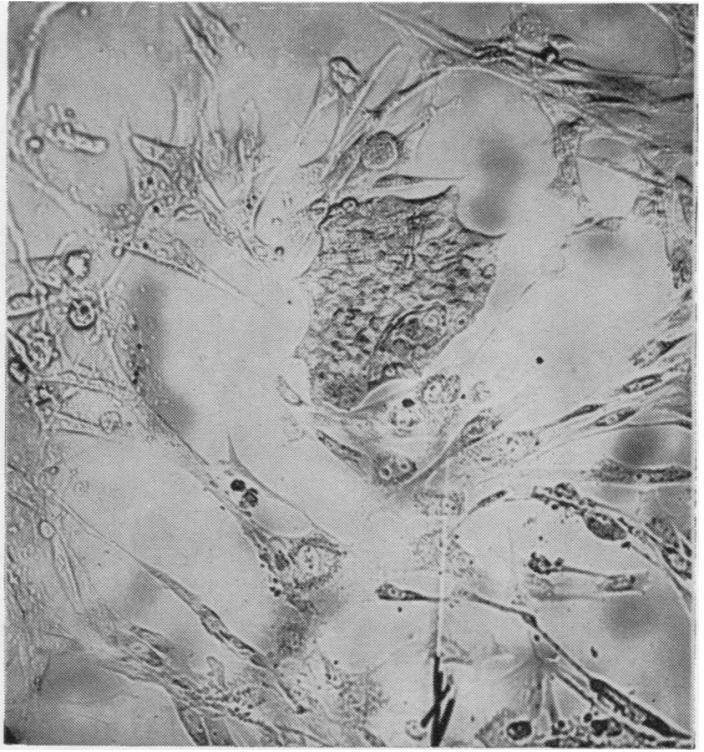

FIG. 9.-Ascitic fluid showing plaque of neoplastic cells surrounded by mesothelial cells in fibroblast-like form in 13-day bottle culture. Carcinoma of gall bladder. $\times 120$.

\section{Discussion}

Examination by phase-contrast microscopy is rapid, and in this series the numbers of malignant cells missed by this method but picked up in stained films have been small-about $2 \%$. The disadvantages include not having a permanent specimen for filing but only a photograph. There is a case for both methods to be used in parallel.

Cultural methods are of use as a concentration method and in comparatively rare cases when doubt exists as a result of examination of films.

\section{Summary}

The examination of the living cells in malignant exudates by phase-contrast microscopy and tissue culture techniques is described.

Thanks are due to Mr. J. A. Haynes for technical assistance, to Mr. W. D. Tredinnick for photography, and to the staff of the Westminster Hospital and Professor D. W. Smithers of the Royal Marsden Hospital for providing material. This work was made possible by a grant from the British Empire Cancer Campaign.

\section{REFERENCES}

Dulbecco, R., and Vogt, M. (1954). J. exp. Med., 99, 167.

Fawcett, D. W., and Vallee, B. L. (1952). J. Lab. clin. Med., 39, 354. Tallee, B. L., and Soule, M. H. (1950). Science, 111, 34.

Hadley, G. G., and Larson, N. L. (1953). Amer. J clin. Path, $23,613$. Humble, J. G., Jayne, W. H. W., and Pulvertaft, R. J. V. (1956).

Pulvertaft, R. J. V., Haynes, J. A., and Groves, J. T. (1956). Exp. Cell Res., 11, 99.

Spriggs, A. I. (1957). The Cytology of Effusions in the Pleural, Pericardial and Peritoneal Cavities, p. 29. Heinemann, London. Syverton, J. T. (1957). Personal communication. Zwilling, E. (1954). Science, 120, 219. 